\title{
The undergrowth composition and distribution in different forest area utilization
}

\author{
SIMON H. SIDABUKKE ${ }^{1, \bullet}$, TERNALA ALEXANDER BARUS ${ }^{2}$, BUDI UTOMO ${ }^{3}$, DELVIAN ${ }^{3}$ \\ ${ }^{1}$ Doctoral Program in Natural Resources and Environment Management, Graduate School, Universitas Sumatera Utara. Jl. Sivitas Akademika No. 9, \\ Medan 20222, North Sumatra, Indonesia. Tel./fax.: +62-61-8226737, `email: simon201265@ gmail.com \\ ${ }^{2}$ Faculty of Mathematics and Natural Sciences, Universitas Sumatera Utara. J1. Bioteknologi No. 1, Medan 20222, North Sumatra, Indonesia \\ ${ }^{3}$ Faculty of Forestry, Universitas Sumatera Utara. J1. Tridharma Ujung No. 1, Medan 20222, North Sumatra, Indonesia
}

Manuscript received: 30 September 2021. Revision accepted: 8 November 2021.

\begin{abstract}
The undergrowth composition and distribution in different forest area utilization. 2021. Sidabukke SH, Barus TA, Utomo B, Delvian. Biodiversitas 22: 5255-5261. Forests provide natural raw materials to support various human activities and also demonstrate a wide range of biodiversity, both in terms of wildlife and plants. Based on biological resources, undergrowth species form a significant portion of the forest ecosystems and have overgrown the typical wooden plants. These ground cover/undergrowth groups are known to exhibit diverse complexities and a type of basic vegetation existing under the forest stands. Therefore, the purpose of this study is to determine the composition and distribution of undergrowth species in each forest area designation, including industrial, protected and natural forests. The plot technique was employed, with an area of $2 \mathrm{~m} \times 2 \mathrm{~m}$. This involves a total of 480,224 and 96 plots in the industrial plantations, protected and natural forest areas, respectively. Also, the entire plants in the measuring plot were recorded, starting from the sprouts up to $1.5 \mathrm{~m}$ high. Subsequently, the important value index (IVI) and Morisita index methods were applied in the data analysis. The results showed the occurrence of 98, 57 and 33 undergrowth species in industrial, protected as well as in natural forests, correspondingly. Based on the important value index calculations, Sintrong species (Crassocephalum crepidioides) reported the maximum IVI (31.587\%) in industrial forest plantations, alongside Senduduk (Melastoma malabathricum) and Paku Wangi (Phymatosorus scolependria) in the protected areas $(29.951 \%)$ and natural forests $(29.551 \%)$, respectively. Furthermore, the Morisita index indicated that the undergrowth distribution pattern for the three areas was clustered, uniform and random, but with varying percentages. However, only two distribution patterns, including random and clustered were peculiar to the natural forests.
\end{abstract}

Keywords: Composition, distribution pattern, important value index, Morisita index, undergrowth

\section{INTRODUCTION}

Forests are very complex natural ecosystems, which combine woody vegetation and shrubs with soil, animals, microorganisms and other natural components that are interconnected in their development and influence each other in the environment (Pan et al. 2013). The diversity of forest vegetation is influenced by various factors, termed physical, chemical and climatic environments that are intricately interconnected to form a unique ecosystem (Fitter et al. 2012). In addition, other elements include the structure and composition, including trees, saplings, shrubs, herbs, grasses, horizontal distribution as well as abundance and human activities (Chapin et al. 2011).

Vegetation diversity is a complex and dynamic collection of various communities, separately composed of mutual plant species in the form of trees, saplings, and undergrowth (varieties that are under the auspices of other vegetations). This layer creates a second-level structure underneath the main header. The presence of understorey functions in absorption and helps to withstand the direct fall of water. And can also play a role in inhibiting or preventing erosion that takes place quickly (Etuk et al. 2020). Ground cover plant communities have a very important role in maintaining and protecting forest. Understorey plant function both ecologically and economically. Ecologically the understorey functions to protect the soil from raindrops, reduce the air velocity of the soil surface, as a habitata for various type of animals and will also significantly increase the nitrogen conten of the soil (Burianek et al. 2013). The undergrowth types are annual, biennial, perennial and the distribution pattern possibly occur randomly, in clumps/groups, and evenly. The presence of undergrowth on the forest floor can function as a barrier to rainwater and surface runoff thereby minimizing the risk of erosion. The species plays a significant role in forest ecosystems and helps to determine the microclimate (Firdaus et al. 2017).

The structure and composition of plant vegetation are influenced by other relating ecosystem components. Therefore, natural-growing species is the result of the interaction of the various environmental factors. This circumstance also affects the distribution pattern, leading to three basic forms, termed random, regular, and clustered. Furthermore, the variations in structure, composition and distribution pattern in each undergrowth strata are related to environmental conditions. Changes in land cover have an impact on the microclimate conditions of a habitat, as well as the diversity of plants, particularly undergrowth. Disturbances can create abrupt changes in understory light and resource availability, and also having a long-term impact on forest dynamics, all of which influence understory populations. The process of HTI development 
and forest area fragmentation will affect the composition of vegetation types in protected areas and natural forests, which are expected to change as a result of fallen trees, broken, disturbed plant crowns caused by wood harvesting activities, maintenance/chemical spraying, resulting in gaps or gaps open places). With a gap, sunlight will reach the forest floor's surface and be gradually followed by the growth of seeds and natural saplings as the soil surface temperature increases. As a consequence, protected areas and natural forests bordering the operational regions of HTI development activities (cultivation) may have become sensitive to changes in plant species composition. Based on these considerations, this study is aimed at determining the composition and distribution of undergrowth species in each forest utilization, including industrial plantation, protected area and natural forest. The resulting data and information are very important in the context of conservation and sustainability.

\section{MATERIALS AND METHODS}

\section{Study area}

This research was conducted in three different locations of North Sumatra Province, Indonesia (Figure 1), termed the work section of the Timber Forest Product Utilization Business Permit - Plantation Forest or known as the TFPUBP-PF of Toba Pulp Lestari company, Estate Aek Nauli and Estate Tele in the cultivation region (principal crops), a protected zone within the concession segment of the company including the river borders, germplasm conservation areas (GCA), other animal protection areas (OAPA) and natural forest areas in Partungko Naginjang as well as the natural forests in special-purpose forest areas (SPFA) of the Institute for Environmental Research and Development of Forestry (IERDF) Aek Nauli, Simalungun Regency, Sumatra province. The research location condition can be presented in Figure 2.
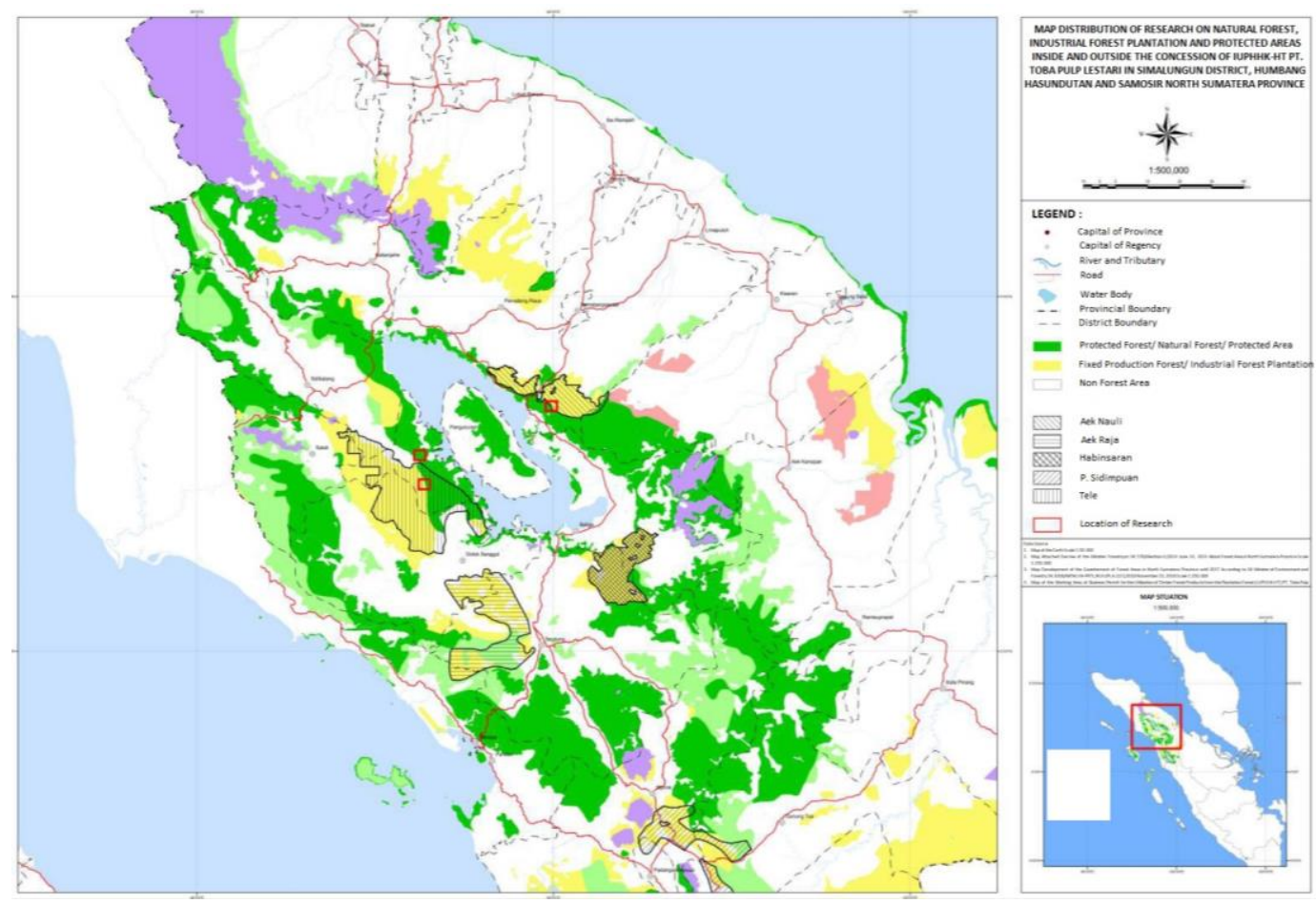

Figure 1. Map of TFPUBP-PF work area Toba Pulp Lestari company, North Sumatra, Indonesia
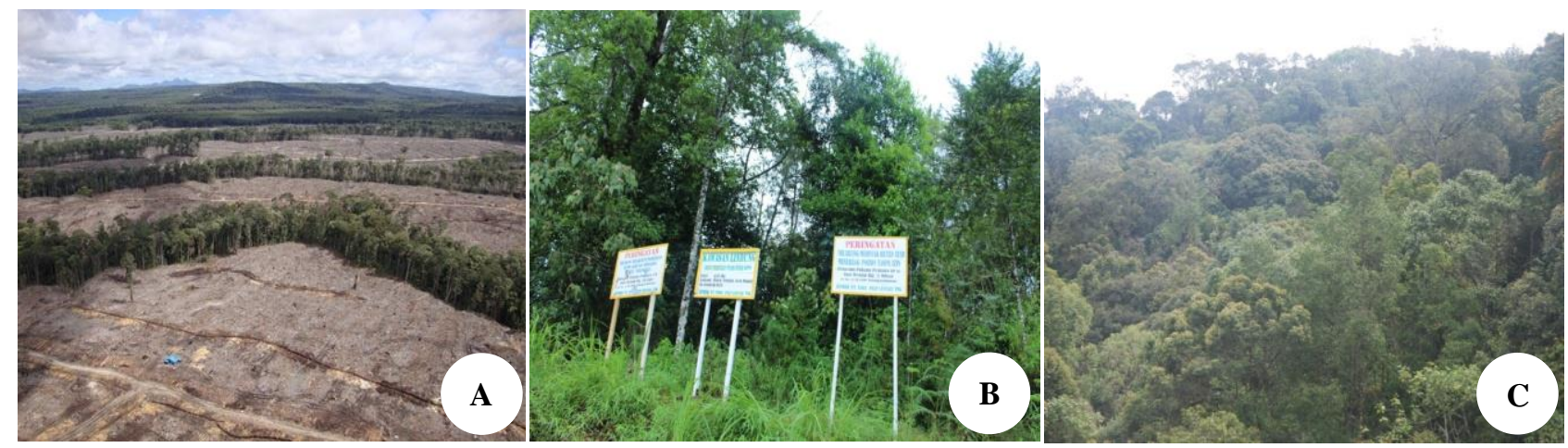

Figure 2. A. Industrial forests (IF), B. Protected areas (PA), C. Natural forests (NF) 


\section{Data collection and analysis}

The data in the industrial forests (IF) and natural forests located outside IF concessions, is obtained using vegetation analysis activities. This process involves calculating the number of sample plots to be measured with the minimum species-area curve (MSAC) with the plotted path method. Each measuring plot $(2 \mathrm{~m} \times 2 \mathrm{~m})$ is placed on the left and right of the lane by recording the complete regeneration from sprouts to seedlings at a height below $1.5 \mathrm{~m}$ (Patana and Latifah 2017). However, for forest groups with an area of 1,000 ha or more, the sampling intensity is expected to be $2 \%$, while below 1,000 ha ranges from $5-10 \%$. This evaluation was measured in meters $(\mathrm{m})$, and the distances between lanes and plots were 20 and $10 \mathrm{~m}$, respectively. Also, the determination of the number of undergrowth sections was based on the minimum area that is representative of the analyzed plant community. Furthermore, the number of plots measured in industrial forest plantations, protected areas as well as in natural forests were 480, 224 and 96, respectively.

\section{Plant composition}

The quantitative data used to determine the plants' composition in various forests is based on the magnitude of the important value index (IVI) of the undergrowth species. This is obtained as the sum of the relative density and relative frequency in the formula below:

$$
\begin{aligned}
& \mathrm{F}=\frac{\text { individuals number of each species }}{\text { total number of plots }} \\
& \mathrm{D}=\frac{\text { number of plots found species }}{\text { total number of plots }}
\end{aligned}
$$

Value of relative density (RD) and relative frequency (RF):

$$
\begin{aligned}
\mathrm{RD} & =\frac{\text { density of a species }}{\text { density of all species }} x 100 \% \\
\mathrm{RF} & =\frac{\text { frequency of a species }}{\text { frequency of all species }} \times 100 \%
\end{aligned}
$$

Undergrowth IVI $=\mathrm{RD}+\mathrm{RF}$

\section{Plant distribution}

Analysis of understorey distribution pattern in each forest area designation uses the standardized Morisita index (Sunardi et al. 2017). This formula is used to determine the distribution pattern of plant species, including the even (uniform), group (clumped), and random forms. The Morisita formula is represented in the following equation:

$$
I \delta=n\left(\frac{\sum X_{i}^{2}-\sum X_{i}}{\left(\sum X_{i}\right)^{2}-\sum X_{i}}\right)
$$

Where:

$I \delta \quad$ : Number of measuring maps

$\mathrm{n} \quad$ : Sample size

$\Sigma X_{i}^{2}$ : The square sum of the total individuals of a species in a community

$\Sigma X_{i}:$ The total number of individuals of a species in a community

\section{RESULTS AND DISCUSSION}

\section{Environmental conditions}

The environmental conditions at the research sites have slight differences in physical conditions (humidity, light intensity, etc.), different regional management patterns, and human intervention in the management of the area. In this industrial plantation forest, the canopy of the Eucalyptus tree is open so that there is a chance for sunlight to reach the forest floor causing high stimulation of understorey plants, seeds, rhizomes, seeds to quickly germinate and grow. Meanwhile, in protected areas and natural forests, the plant canopy is more dense and closed. The pattern of forest area management, including industrial plantation forests which are managed all the time (dynamically) by humans, starting from the preparation stage for planting areas for staple crops (monoculture), plant maintenance and harvesting of Eucalyptus, when compared to the management of other areas of protected areas and natural forests. which tends to be completely static, the changes that occur tend to depend on nature with minimal treatment from humans. In this industrial plantation forest, the canopy of the Eucalyptus tree is open so that there is a chance for sunlight to reach the forest floor causing high stimulation of understorey plants, seeds, rhizomes, seeds to quickly germinate and grow. Meanwhile, in protected areas and natural forests, the plant canopy is more dense and closed.

\section{Undergrowth type composition}

The number of undergrowth species varies in each forest area designation. Also, the regions with the maximum population in a row are the industrial forests (IF), protected areas (PA) and natural forests (NF). A total of 139 distinct species were identified in the entire research area, where 98 only existed in IF. However, the undergrowth category in IF, PA and NF were 64, 22 and 15 , respectively. Several species were also observed in similar locations. For instance, IF and PA, IF and NF, as well as PA and NF reported 20, 3, and 4 species, respectively. Based on the Venn diagram (Figure 3), IF (64) and PA (22) showed a total number of 86 species, but only 20 similar species were common in these two forests area designations. Furthermore, 11 undergrowth types occurred in the entire three locations, possibly due to the very wide living niches that tend to develop with various physical conditions.

The diversity of plant species in IF appears higher, compared to the other two areas. However, the variation in numbers and families at the three research locations is probably attributed to the distinct adaptations and needs of individual species. The adaptation to environmental conditions also instigates alterations in the number of plant species, while the sunlight is related to the high species abundance in IF. Eucalyptus tree canopies are slightly slender, light, and allow for sufficient sunshine, compared to PA and NF with denser crowns. This observation is supported by $\mathrm{Xu}$ et al. (2011), where intense sunlight is needed for plant survival. Differences in structure and composition in each understorey strata are closely related 
to habitat conditions. Environmental factors that will affect the existence of growth is the altitude above sea level. Altitude will affect species richness, structure and composition of understorey vegetation, soil conditions, temperature, light and water intensity (Mishra et al. 2017).

Table 1 shows the 5 undergrowth species with maximum important value index (IVI). A high estimate indicates extensive dominance and adaptability, compared to other species. According to Malik et al. (2019), one of the environmental conditions that have the most influence on plant growth under stands include sunlight and shade. A high significance index indicates that the species has the highest number of individuals, and the density and frequency found in the community are also high. The highest importance value index identifies that these species affect the stability of the ecosystem as a whole (Winata et al. 2017). The high IVI value means that a species is dominant and has better adaptability than other species (Astari et al. 2020).

Sintrong (Crassocephalum crepidioides) of the Asteraceae family is the most dominant species in the industrial forest. This plant exhibits a wild growth rate in tropical and sub-tropical areas and tends to adapt effectively to various disturbing environmental conditions, fields, land clearing, roadside, riverbanks, and also shrubs. The species also contain compounds with the potentials for antibacterial and antioxidant properties (Sari 2016). A high IVI is possibly due to the suitability of light needs, considering that it is a variety that requires a relatively high sunlight intensity. Senduduk (Melastoma malabathricum) of the Melastomataceae family showed the maximum IVI in the protected areas. The species grows wildly in regions with adequate sunlight, including mountain slopes, shrubs, less arid fields. Previous research reported that the plant is comfortable under wood canopies with less dense conditions, this was also among the factors for the high IVI in PA and IF zones (Dharmawan and Wicaksono 2019). Wangi (Phymatosorus scolependria) demonstrated the greatest IVI in the natural forest. This species typically grows in disturbed areas, secondary forests and rock crevices, but also exists in the middle of undergrowth vegetation at low elevations. Furthermore, the plant dominance is related to relatively low light intensity and high humidity, with similarity to ferns.

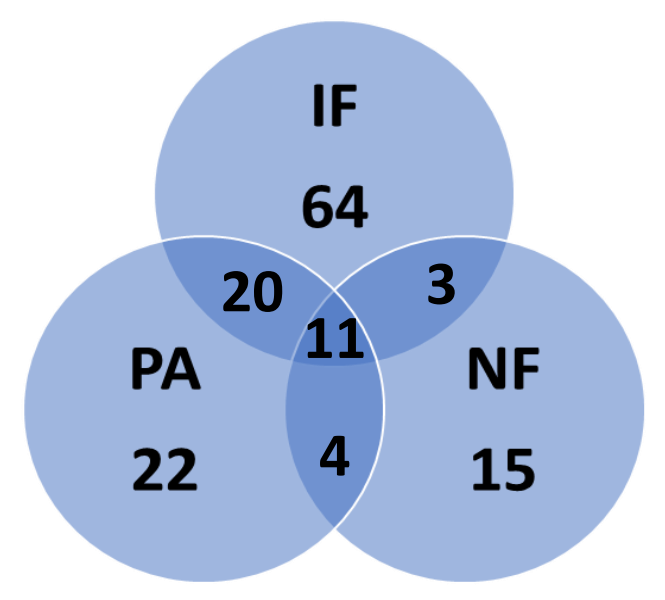

Figure 3. Venn diagram composition of undergrowth species in each forest area designation (Industrial Forests (IF), Protected Areas (PA) and Natural Forests (NF))

Table 1. The 5 undergrowth species with the largest IVI in each forest type

\begin{tabular}{llll}
\hline Local name & Scientific name & Family & IVI Value (\%) \\
\hline Industrial forest & & & 31.587 \\
Sintrong & Crassocephalum crepidioides & Asteraceae & 24.849 \\
Senduduk & Melastoma malabathricum & Melastomataceae & 19.551 \\
Kentangan & Boreria alata & Rubiaceae & 17.671 \\
Pegagan & Centella asiatica & Apiaceae & 6.856 \\
Rotan & Calamus erectus & Arecaceae & \\
& & & 29.951 \\
Protected area & Melastoma malabathricum & Melastomataceae & 21.311 \\
Senduduk & Marchantiaa polymorpha & Marchantiaceae & 12.007 \\
Lumut daun & Zingiber officinale & Zingiberaceae & 10.787 \\
Jahe liar & Lycopodium cervuum & Lycopodiaceae & 10.264 \\
Paku kawat & Calamus erectus & Arecaceae & \\
Rotan & & & \\
& Phymatosorus scolependria & Polypodiaceae & 29.951 \\
Natural forest (out of concession) & Selaginellaceae & 21.729 \\
Paku Wangi & Phymela doederleinii & Gleicheniaceae & 15.930 \\
Cakar Ayam & Dicranopteris linearis & Lycopodiaceae & 13.076 \\
Rasam & Lycopodium cervuum & Pteridaceae & 11.111 \\
Paku kawat & Adiantum tenerum & & \\
Suplir daun lebar & & & \\
\hline
\end{tabular}


Table 2. Distribution pattern of undergrowth species in each forest area designation

\begin{tabular}{llll}
\hline Forest & \multicolumn{3}{c}{ Distribution type } \\
& Random & Uniform & Clustered \\
\hline Industrial forest & 8 species & 10 species & 80 species \\
& $(8.16 \%)$ & $(10.20 \%)$ & $(81.63 \%)$ \\
Protected area & 6 species & 8 species & 43 species \\
& $(10.52 \%)$ & $(14.03 \%)$ & $(75.43 \%)$ \\
Natural Forest & 3 species & none $(0 \%)$ & 30 species \\
& $(9.09 \%)$ & & $(90.91 \%)$ \\
\hline
\end{tabular}

\section{Distribution pattern of undergrowth}

The distribution of understorey species was found in the entire research area with a distribution of 98 species in IF, 57 species in PA, 33 species in NF having different distribution patterns in three forms, which are called random, clustered (clumped) and uniform (Odum 1998). The results of observations at the research location show that the distribution pattern is clustered which dominates compared to other distribution patterns. Information the pattern is used to indicate the location of the plant's preferences and is influenced by the variations in soil conditions, resources and competition (Safniyeti et al. 2017). The value of the distribution pattern was tried by calculating the Morisita dispersion index (IP) which is presented in Table 2.

Based on the Morisita index value, the species distribution remains dominated by clustered, and is followed by the random and uniform pattern. Consequently, the random category indicates a homogeneous environmental condition or a non-selective behavior pattern of living matter. This type tends to be safer for plant management efforts. A uniform/regular distribution pattern occurs when there is strong competition between individuals in the group (Xu et al. 2011). Also, the random form generally occurs for plants due to the scattering of the plant seeds by wind and the environmental conditions are uniform. In addition, there is no tendency for individuals to segregate as possessed by the plant's reproductive organs that are composed of 24 species. Distribution patterns have a close relationship with environmental conditions, species are interdependent, and if there is a disturbance to the species or environmental factors it usually results in a distribution pattern (Crossman et al. 2011).

The clusters (clumped) appear as the most common distribution pattern in nature (Odum 1998). This conclusion is related to the competition for nutrients and space. Also, due to the adaptation to environmental conditions, there is typically an increase in the contest for nutrients, space, and light with other stronger species. Based on socio-ecology, the distribution pattern indicates that the presence of food/beverage is concentrated in certain locations. This circumstance also shows the existence of social interaction between these plants. One of the reasons for the clustered pattern is that environmental conditions are rarely uniform, even in a narrow region (Wijana and Setiawan 2019). According to Mligo (2017), the distribution pattern of plant species tends to cluster, because plants reproduce by producing seeds that fall near their parents or by rhizomes that produce vegetative tillers that are still close to their parents. Therefore, plant populations in nature are generally distributed in clusters and only slightly spread in other patterns. Ludwig and Reynolds (1988), proposed that the factors influencing the spatial distribution pattern of living organisms are: (a). vectorial, and are produced by environmental actions, including soil type, wind, light, and water intensity, (b). social, as related to the organism behavior, e.g territorial, (c). co-active, as connected to intraspecific interactions (d). stochastic, due to the results from random variations in several previous factors.

In general, the pattern of clustering in various growth rates of a species is the pattern that is most often found when studying the distribution of individuals in nature (Ahmed et al. 2020). Furthermore, according to Subedi et al. (2015) states that the formation of the distribution pattern is influenced by various mechanisms. Various processes of interaction both biotic and abiotic contribute to each other to form the distribution pattern. And due to differences in environmental conditions, resources, neighboring plants, and disturbances which are factors that affect the dynamics of plant population patterns. These differences in environmental conditions not only modify the distribution and abundance of individuals, but also change the growth rate, seed production, branching patterns, leaf area, root area, and individual size (Hájek et al. 2011). In conclusion, the clustered distribution was instigated by the heterogeneity of environmental factors from where the growth source (Ludwig and Reynolds 1988). Meanwhile, in plants with random distribution is due to the scattering of seeds by the wind. This occurs in uniform environmental conditions, with no segregation tendency. The reason for knowing these patterns is that it can help in making decisions about what method to use to estimate the density or abundance of a population (Shomurodov et al. 2015).

The pattern of distribution is an important character in community ecology which was first observed in seeing the existence of several communities which is one of the basic characteristics for most groups of living organisms. Two populations may have the same density, but have significant differences in distribution patterns (Chellappan et al. 2013). Knowledge of distribution is very important to determine the level of grouping of individuals that can have an impact on the population (Kieltyk 2014). According to Ludwig and Reynolds (1988), the variation in distribution patterns is caused by several interacting factors, including (i) internal environmental factors, including wind, water availability and light intensity, (ii) reproductive capacity, (iii) social influences related to plant phenology, (iv) coactive factors from intraspecific interactions, and (v) factors resulting from random variations in some of the above factors. Distribution, survival, growth and reproduction patterns reflect the adaptation of plants to certain environments. This situation becomes an important part of plant ecology (Dai et al. 2013). There is a limiting factor to population existence, probably as a result of the relatively heavier topography (wavy-hilly) and 
the field condition in particular rocky paths with a thin topsoil layer and unstable cultivation sites.

Clustering patterns tend to increase competition for nutrients, space and sunlight. The clustered distribution pattern shows that the presence of a plant will give an indication to find similar plants, this is because individuals have a tendency to gather and look for environmental conditions that suit their needs. The grouping is done because of the mutually beneficial interactions between these individuals (Zhang et al. 2012). Also, the undergrowth distribution in natural forests that are distant from the industrial plantations consists of 33 plant species. Furthermore, there are $3(9.09 \%), 30(90.91 \%)$ and 0 species $(0 \%)$ in the random, group, and uniform distribution types, respectively.

There are no specific distribution patterns for different areas found in this study. Except in natural forest, only clustered and random distribution patterns can be found. This is in accordance with Sajib et al. (2016) which states that the distribution pattern in nature is rarely found in a uniform (regular) pattern, but generally has a clustered pattern. This is not only caused by environmental factors and competition which can be a limiting factor for growth, it is also influenced by the reproductive ability of the plant itself. Knowing the pattern of distribution of plants is important as a basic management data, namely the placement of plants in the spatial dimension. In addition, the distribution pattern can indicate the location of the plant's preferences. The physical condition of the environment is a very important factor in determining the distribution pattern of a plant. The clustered distribution pattern can occur because it is caused by the physical conditions of the environment that are rarely uniform, even in a narrow location (Zhang et al. 2014). The random distribution pattern indicates a homogeneous environmental condition or shows a non-selective behavior pattern of living things on environmental conditions. Random distribution patterns tend to be safer for plant management efforts. The uniform/regular distribution pattern indicates a negative interaction between individuals.

To conclude, the diversity of undergrowth species in the three forests type showed distinct values. The highest number of species found in industrial forest area with 98 species, followed by protected area with 57 species and natural forest with 33 species. The different abundant of species in each location is related to the suitability of light intensity as a basic plant requirement. Based on the important value index, Sintrong (Crassocephalum crepidioides) has the highest IVI in the industrial forest. In protected area Senduduk (Melastoma malabathricum) was the highest IVI species while in natural forest Paku Wangi (Phymatosorus scolependria) was the highest. The understorey distribution found in three type namely, cluster, random and uniform pattern. The highest percentage found in clustered group, followed by random and uniform. However, uniform patterns were not observed in natural forests.

\section{REFERENCES}

Ahmed MJ, Murtaza G, Shaheen H, Habib T. 2020. Distribution pattern and associated flora of Jurinea dolomiaea in the western Himalayan highlands of Kashmir: An indicator endemic plant of alpine phytodiversity. Ecol Indic 116: 106461. DOI: 10.1016/j.ecolind.2020.106461.

Astari W, Rosleine D, Lastini T, Wahyu JC, Manggala R. 2020. Vegetation analysis and carbon stock estimation in Kuningan Botanical Garden West Java. IOP Conf Ser: Earth Environ Sci 528 (1). DOI: 10.1088/1755-1315/528/1/012002.

Burianek VR, Novotny K, Hellebrandova V, Sramek. 2013. Ground vegetation as an important factor in the biodiversity of forest ecosystem and its evaluation in regard to nitrogen deposition. J For Sci 59 (6): 238-252. 10.17221/16/2013-JFS.

Chapin FS, Matson PA, Vitousek PM. 2011. The ecosystem concept. Principles of terrestrial ecosystem ecology. Springer, New York. DOI: 10.1007/978-1-4419-9504-9_1.

Chellappan M, Lawrence L, Indhu P, Cherian T, Anitha S. 2013. Host range and distribution pattern of papaya mealy bug, Paracoccus marginatus Williams and Granara de Willink (Hemiptera: Pseudococcidae) on selected Euphorbiaceae hosts in Kerala. J Trop Agric 51 (1): 51-59.

Crossman ND, Bryan BA, Cooke DA. 2011. An invasive plant and climate change threat index for weed risk management: integrating habitat distribution pattern and dispersal process. Ecol Indic 11 (1): 183-198. DOI: 10.1016/j.ecolind.2008.10.011.

Dai XH, Xu JS, Ding XL. 2013. Circular distribution pattern of plant modulars and endophagous herbivory within Tree crowns: The impact of roadside light conditions. J Insect Sci 13 (1): 1-17. DOI: 10.1673/031.013.14101.

Dharmawan AA, Wicaksono KP. 2019. Pengaruh kepadatan kanopi kayu putih (Eucalyptus pellita) umur 1 dan 1, 5 tahun pada komposisi gulma. Jurnal Produksi Tanaman 7 (7): 1-8. [Indonesian]

Etuk IM, Daniel KS, Umoh UA. 2020. Ecology of undergrowth plant species in four selected natural forests in Akwa Ibom State, Nigeria. Ecology 3 (4): 12-34.

Fitter AH, Mace GM, Norris K. 2012. Biodiversity and ecosystem services: a multilayered relationship. Trends Ecol Evol 27 (1): 19-26. DOI: 10.1016/j.tree.2011.08.006.

Firdaus LN, Wulandari S, Syafi'i W, Fauziah Y. 2017. Post-fire peat land understory plant in Rimba Panjang, Sumatera, Indonesia. IOP Conf Ser: Earth Environ Sci 97 (1). International Conference on Environment and Technology (IC-Tech) 2017 26-27 July 2017, Pekanbaru, Indonesia. DOI: 10.1088/1755-1315/97/1/012033.

Hájek M, Horsák M, Tichý L, Hájková P, Dítě D, Jamrichová E. 2011. Testing a relict distributional pattern of fen plant and terrestrial snail species at the Holocene scale: a null model approach. J Biogeogr 38 (4): 742-755. DOI: 10.1111/j.1365-2699.2010.02424.x.

Kiełtyk P. 2014. Distribution pattern of the invasive alien plant Bunias orientalis in Rów Podtatrzański trench, north of the Tatra Mts, Poland. Biologia 69 (3): 323-331. DOI: 10.2478/s11756-013-0319-7.

Ludwig JA, Reynolds JF. 1988. Statistical Ecology: A Primer on Methods and Computing. John Wiley and Sons, Singapore.

Malik A, Rahim A, Sideng U. 2019. Biodiversity assessment of mangrove vegetation for the sustainability of ecotourism in West Sulawesi, Indonesia. Aquacult Aquarium Conserv Legislation-Intl J Bioflux Soc (AACL Bioflux) 12 (4): 1458-1466. [Indonesian]

Mishra T, Singh NB, Singh N. 2017. Restoration of red mud deposits by naturally growing vegetation. Intl J Phytoremed 19 (5): 439-445. DOI: $10.1080 / 15226514.2016 .1244162$.

Mligo C. 2017. Diversity and distribution pattern of riparian plant species in the Wami River system, Tanzania. J Plant Ecol 10 (2): 259-270. DOI: $10.1093 /$ jpe/rtw021.

Odum EP. 1998. Ecología: el puente entre ciencia y sociedad (No. Sirsi) i9789701019061. McGraw-Hill Interamericana, Mexico.

Pan Y, Birdsey RA, Phillips OL, Jackson RB. 2013. The structure, distribution, and biomass of the world's forests. Ann Rev Ecol Evol Syst 44: 593-622. DOI: 10.1146/annurev-ecolsys-110512-135914.

Patana P, Latifah, S. 2017. Spatial analysis on distribution of green belt to reduce impacts of climate change in Medan City, North Sumatra. Malay Appl Biol 46 (2): 67-76.

Safniyeti S, Sulistijorini S, Chikmawati T. 2017. Diversity and distribution of Myrmecophytes in Bengkulu Province. Biosaintifika: 
Journal of Biology \& Biology Education 9 (2): 273-281. DOI: 10.15294/biosaintifika.v9i2.9285. [Indonesian]

Sajib NH, Uddin SB, Islam MS. 2016. Vascular plant diversity and their distribution pattern in Sandwip Island, Chittagong, Bangladesh. J Biodivers Manag For 5 (2): 1-5. DOI: 10.4172/2327-4417.1000159.

Sari AN. 2016. Berbagai tanaman rempah sebagai sumber antioksidan alami. Journal of Islamic Science and Technology 2 (2): 203-212. DOI: 10.22373/ekw.v2i2.2695. [Indonesian]

Shomurodov HF, Saribayeva SU, Akhmedov A. 2015. Distribution pattern and modern status of rare plant species on the Ustyurt Plateau in Uzbekistan. Arid Ecosyst 5 (4): 261-267. DOI: 10.1134/S2079096115040125.

Subedi SC, Bhattarai KR, Chauudhary RP. 2015. Distribution pattern of vascular plant species of mountains in Nepal and their fate against global warming. J Mount Sci 12 (6): 1345-1354. DOI: 10.1007/s11629-015-3495-9.

Sunardi S, Sulistijorini S, Setyawati T. 2017. Invasion of Acacia decurrens Willd. after eruption of mount Merapi, Indonesia. BIOTROPIA-Southeast Asian J Trop Biol 24 (1): 35-46. DOI: 10.11598/btb.2017.24.1.524.

Wijana N, Setiawan IGN. 2019. Mapping and distribution of useful plant species in Bukit Kangin Forest, Pegringsingan Village, Karangasem,
Bali. International Conference on Innovative Research Accros Discipline (ICIRAD) 394: 87-94

Winata A, Yuliana E, Rusdiyanto E. 2017. Diversity and natural regeneration of mangrove vegetation in the tracking area on Kemujan Island Karimunjawa National Park, Indonesia. Adv Environ Sci 9 (2): 109-119.

Xu Q, Zhang W, An S, Xu Z, Cui J. 2011. The impact of vegetation and soil on runoff regulation in headwater streams on the east QinghaiTibet Plateau, China. Catena 87 (2): 182-189. DOI: 10.1016/j.catena.2011.05.020.

Xu Y, Chen Y, Li W, Fu A, Ma X, Gui D, Chen Y. 2011. Distribution pattern of plant species diversity in the mountainous Region of Ili River Valley, Xinjiang. Environ Monit Assess 177 (1): 681-694. DOI: 10.1007/s10661-010-1665-3.

Zhang Y, JiMei LI, Chang S, Xiang LI, JianJiang LU. 2012. Spatial distribution pattern of Picea schrenkiana population in the Middle Tianshan Mountains and the relationship with topographic attributes. J Arid Land 4 (4): 457-468. DOI: 10.3724/SP.J.1227.2012.00457.

Zhang Z, Yu Y, Hua L, Pu X, Wang H, Liang T. 2014. Analysis of the distribution pattern of wild vascular plant diversity in Gansu Province, China. Acta Prataculturae Sinica 23 (3): 22-30. 